\title{
ANALISIS KEBUTUHAN GURU MATA PELAJARAN PRODUKTIF DI INDUSTRI PENDIDIKAN MENENGAH MELALUI PEMODELAN MATEMATIKA
}

\author{
Taufik Hidayat, Hasbullah Hasbullah \\ Magister Teknik Industri, Universitas Mercu Buana, Jakarta
}

\begin{abstract}
Vocational Teacher Needs in productive subject programs (Practical Teachers) have an important role in producing competent SMKs. This study aims to provide a model for the procurement of productive teacher needs.At present the need for productive subject teachers is less than 120,000 compared to the number of SMK students of more than 5,000,000(DitPSMK, 2016). In this study using a mathematical model through the calculation of multiple linear regression models on the variable Number of SMK Students, industry needs, number of SMKs and the budget.The results of this study are a mathematical model in determining the needs of productive teachers $Y=280966-41.6 X 1$ - $12.47 X 2+33.4 X 3-20.7 X 4$.
\end{abstract}

Keywords: Vocational Teacher, Multiple Linear Regression, Mathematical Modeling

\section{Pendahuluan}

Saat ini jumlah populasi penduduk Indonesia lebih dari 235 juta, (Badan Pusat Statistik, 2018) peringkat terbesar ke-4 di dunia. Hal ini merupakan pasar potensial bagi negara - negara lain untuk masuk dalam persaingan industri di era pasar bebas, baik dari sisi produk maupun dari sisi tenaga kerja. Bangsa Indonesia tentunya harus mempersiapkan segala hal agar tidak menjadi penonton ataupun konsumen di Negara sendiri. Berdasar pada trend perkembangan penduduk Indonesia saat ini, maka diprediksi tahun 2025 Indonesia akan menerima bonus demografi yang berpengaruh pada meningkatnya penduduk usia produktif di Indonesia. Langkah pemerintah dalam meningkatkan kualitas sumber daya manusia dilakukan melalui pendidikan kejuruansalah satunya Sekolah Menengah
Kejuruan (SMK). Lulusan SMK dituntut dapat bersaing dalam era pasar bebas yang saat ini telah masuk ke dalam industri 4.0. Namun sangat disayangkan bahwa saat ini lulusan SMK menempati posisi pertama Tingkat Pengangguran Terbuka (TPT) atau yang tertinggi dibanding dengan tingkat pendidikan yang lainnya sebesar 11,24 persen. (Badan Pusat Statistik, 2018)

Untuk mengatasi masalah tersebut pemerintah menerbitkan Instruksi Presiden No. 9 Tahun 2016 mengenai revitalisasi SMK yang mana empat poin yang menjadi fokus dalam upaya meningkatkan kualitas sumber daya manusia, lebih khusus untuk penyediaan tenaga kerja terampil. Keempat poin tersebut mencakup revitalisasi pendidik \& tenaga kependidikan, kurikulum,lulusan 
dan kerja sama. (DitPSMK, 2016). Pendidik merupakan salah saktu faktor terpenting yang mempengaruhi kualitas pendidikan pada suatu negara. Dari segi kompetensi, guru yang berpendidikan Sarjana dan Master/Doktor ternyata memiliki kompetensi yang tidak jauh berbeda dengan guru yang berpendidikan Diploma 3 dan di bawah Diploma 3. (Renstra DitPSMK, 2016).

Guru mata pelajaran produktif pada pendidikan kejuruan memiliki peran penting dalam menghasilkan lulusan SMK yang memiliki karakteristik kompetensiprofessional yang spesifik, antara lain: 1). Memiliki keahlian praktis yang mumpuni pada seluruh bidang studi (mata pelajaran) produktif; 2). Mampu melaksanakan pembelajaran (diklat) yang terkait dengan kompetensi yang dibutuhkan oleh industri; 3. Mampu merancang pembelajaran (diklat) di sekolah dan di industri. (DitPSMK, 2016). Guru mata pelajaran produktif yang ada saat ini berjumlah kurang dari 120.000 orang apabila dibandingkan dengan jumlah siswa/i SMK sebanyak lebih dari 5.000.000 orang (DitPSMK, 2016) maka perbandingannya adalah sekitar $1: 43$, artinya setiap satu orang guru mendidik atau mengajar lebih dari 43 siswa. Ini masih sangat jauh dari rasio guru dan siswa yang ideal yaitu 1:27 (Mulyadi, Setiawan, \& Purnawan, 2010). Penelitian ini mempunyai tujuan untuk menghasilkan sebuah model matematika dan metode perhitungan model regresi linier pengadaan guru mata pelajaran produktif SMK.

\section{Tinjauan Pustaka}

\section{Model Matematika}

Model matematika merupakan sebuah ekspresi kuantitatif mengenai hubungan-hubungan antara berbagai komponen sistem. Beberapa istilah atau terminalogi yang ada pada model matematika, yaitu variabel keputusan, ukuran performansi atau ukuran efektifitas, fungsi tujuan, konstanta/parameter/koefisien, dan pembatas atau kendala (Lathifan \& Nugraha, 2014). Fenomena dan gejala alam yang ada di jagad raya ini hampir semuanya dapat diilustrasikan ke dalam suatu formula matematika. Suatu model yang meniru realita alam dengan menggunakan bahasa matematika dinamakan model matematika.(Mahmudah, 2017)

\section{Model Regresi Linier}

Model regresi linier berganda (Multiple-Linear Regression/MLR) dapat dipakai untuk mengevaluasi hubungan antara variabel terikat dengan dua atau lebih variabel bebas(Permai \& Tanty, 2018). MLR dapat dipaki untuk berbagai kebutuhan diantaranya:

1. Memprediksi nilai rata-rata dari variabel tergantung berbasis pada nilai-nilai variabel penduga yang digunakan

2. Menguji hipotesis tentang sifat-sifat ketergantungan antar variabel.

3. Menaksir atau meramalkan nilai rata-rata dari variabel tergantung berdasarkan nilai variabel bebas yang berada diluar rentang sampel

4. Mengetahui pengaruh masing-masing variable bebas terhadap variabel yang diestimasi (Farizal, Rachman, \& Rasyid, 2014)

Secara umum model regresi dapat dituliskan sebagai berikut :

$$
\begin{array}{cl}
Y=\beta_{0}+\beta_{1} X_{1}+\beta_{2} X_{2}+\cdots+\beta_{n} X_{n}+\varepsilon(1) \\
\text { Dimana: } & Y=\text { Variabel Terikat } \\
& \beta_{0}=\text { Konstanta } \\
& \beta_{1}=\text { Koefisien Regresi } \\
& X_{1}=\text { Variabel Bebas } \\
& \varepsilon=\text { Error }
\end{array}
$$


Pengujian dan analisis dilakukan untuk mengetahui apakah model regresi yang didapatkan merupakan model yang sudah representative dari data-datayang ada. Analisis dan pengujian yang dilakukan adalah sebagai berikut:

1. Pengujian Asumsi Multikolinieritas

Uji asumsi multikolinieritas diketahui dari nilai tolerance dan Variance Inflation Factor (VIF). Jika nilai tolerance kurang dari 1 dan nilai VIF lebih dari 1,0 maka dapat disimpulkan tidak ada multikolinearitas. Mencari nilai VIF didapat dari rumus ;

$$
V I F=\frac{1}{1-R_{j}^{2}}
$$

2. Pengujian Model Regresi

Uji model regresi dilakukan untuk mengecek signifikansi pengaruh variabelvariabel prediktor yang digunakan pada model MLR terhadap nilai variable tergantung yang akan diprediksi. Uji model regresi ini akan menentukan apakah variable prediktor benar mempengaruhi variabel tergantung atau sebaliknya variable tersebut tidak berpengaruh secara signifikan.

3. Pengujian Residual

Karena model regresi yang dibentuk didasarkan pada pendekatan meminimumkan jumlah kuadrat error, maka residual (sisa) yang dalam hal ini dianggap sebagai kesalahan dalam memprediksi harus memenuhi asumsi IIDyaitu identik (memiliki varian yang konstan), independen (saling bebas dan tidak ada autokorelasi antar residual), dan berdistribusi normal. Uji residual dapat dilakukan dengan menggunakan scatter plot. Hasil scatter plot yang acak menunjukkan bahwa model regresi memenuhi syarat IID. Sebaliknya scatter plot yang menunjukkan pola tertentu seperti dua mangkok (double bowl), corong (funnel), dan lembah (curvature) menunjukkan data tidak memenuhi syarat IID yang berarti model MLR kurang tepat untuk digunakan(Farizal, Rachman, \& Rasyid, 2014)

4. Analisis Koefisien Determinasi Koefisien determinasi merupakan proporsi variabilitas dalam suatu data yang dihitung berdasarkan model statistic. Dengan kata lain, koefisien determinasi diartikan dengan seberapa besar variable independen $\mathrm{x}$ menentukan tingkat variable respon y dalam suatu model. Koefisien determinasi berganda dinotasikan dengan $\mathrm{R}^{2}$. Perhitungan dari koefisien determinasi berganda didapatkan dengan rumus berikut :

$$
R^{2}=1-\frac{\Sigma\left(y_{i}-\tilde{y}_{i}\right)^{2}}{\Sigma\left(y_{i}-\tilde{y}\right)^{2}}(3)
$$

Nilai $\mathrm{R}^{2}$ dapat diinterpretasikan sebagai besar dari proporsi variabilitas total dalam variable respon y yang dapat dihitung oleh sekelompok variable bebas $\mathrm{x}_{1}, \mathrm{x}_{2}, \ldots$, $\mathrm{x}_{\mathrm{n}}$. Perhatikan bahwa nilai koefisien determinasi berganda ini $0 \leq \mathrm{R}^{2} \leq 1$. Artinya, jika nilai $\mathrm{R}^{2}=1$ maka model yang dihasilkan mampu menjelaskan semua variabilitas dalam variable $\mathrm{y}$. Namun, jika $\mathrm{R}^{2}=0$, maka tidak ada hubungan antara variable independen (x) dengan variable y. Dengan kata lain, nilai dari $\mathrm{x}_{1}$ sama sekali tidak berpengaruh dalam memprediksi nilai $\mathrm{y}_{1}$. Jika semakin dekat nilai $\mathrm{R}^{2}$ dengan , maka tingkat kecocokan model semakin baik dengan data yang diolah (Kurniawan, Yuniarto, 2016). 
Metodologi

Penelitian ini menggunakan beberapa variable Independen $(\mathrm{X} 1, \mathrm{X} 2, \mathrm{X} 3, \mathrm{X} 4)$ dan satu variable dependent $(\mathrm{Y})$.

Berikut adalah Variabel-variabelnya:

$\mathrm{X} 1$ = Jumlah Siswa SMK

$\mathrm{X} 2$ = Jumlah Anggaran

$\mathrm{X} 3=$ Kebutuhan Industri

$\mathrm{X} 4=$ Jumlah SMK

$\mathrm{Y}=$ Jumlah Guru Mata Pelajaran Produktif
SMK

Selanjutnya, data diproses menggunakan Regresi Linier Berganda kemudian dilakukan pengujian yaitu Uji Multikolinieritas,uji model regresi, uji residual kemudian Analisis terhadap Koefisien Determinasi $\mathrm{R}^{2}$ dan $\mathrm{R}_{\text {adj }}^{2}$, dibantu dengan menggunakan software Minitab 17.

\section{Hasil Dan Pembahasan}

Tabel 1. Data Input Multiple Liner Regression

\begin{tabular}{cccccc}
\hline Tahun & $\begin{array}{c}\text { Jumlah Guru } \\
\text { Produktif }\end{array}$ & $\begin{array}{c}\text { Jumlah Siswa ( } \\
\text { Ribu })\end{array}$ & $\begin{array}{c}\text { Jumlah Anggaran } \\
\text { (Rp. Miliar) }\end{array}$ & $\begin{array}{c}\text { Kebutuhan } \\
\text { Industri } \\
\text { ( Ribu })\end{array}$ & $\begin{array}{c}\text { Jumlah } \\
\text { SMK }\end{array}$ \\
\hline 2010 & 44.423 & 3.704 & 6.977 & 6.377 & 10.054 \\
2011 & 46.761 & 3.858 & 7.344 & 7.086 & 10.583 \\
2012 & 49.222 & 4.019 & 7.730 & 7.873 & 11.140 \\
2013 & 53.057 & 4.189 & 8.131 & 8.748 & 11.726 \\
2014 & 55.920 & 4.199 & 8.559 & 9.720 & 12.421 \\
2015 & 104.003 & 4.211 & 9.009 & 10.800 & 12.659 \\
2016 & 78.208 & 4.334 & 11.542 & 12.100 & 13.236 \\
2017 & 82.830 & 4.678 & 12.060 & 12.500 & 13.710 \\
2018 & 87.664 & 4.899 & 12.390 & 13.600 & 13.856 \\
2019 & 80.000 & 5.014 & 12.972 & 14.600 & 14.604 \\
\hline
\end{tabular}

Tabel 2. Analysis of Variance (ANOVA)

\begin{tabular}{lccccc}
\hline \multicolumn{1}{c}{ Source } & DF & Adj SS & Adj MS & F-Value & P-Value \\
\hline Regression & 4 & 3650493057 & 912623264 & 8,21 & 0,020 \\
X1 & 1 & 203959711 & 203959711 & 1,84 & 0,234 \\
X2 & 1 & 308624737 & 308624737 & 2,78 & 0,157 \\
X3 & 1 & 614763523 & 614763523 & 5,53 & 0,065 \\
X4 & 1 & 116795799 & 116795799 & 1,05 & 0,352 \\
Error & 5 & 555717516 & 111143503 & & \\
Total & 9 & 4206210574 & & & \\
\hline
\end{tabular}


Sumber : Pengolahan Data

Tabel 3. Model Summary

\begin{tabular}{cccc}
\hline $\mathrm{S}$ & R-square & R-sq(adj) & R-sq(prediction) \\
\hline 10542,5 & $86,79 \%$ & $76,22 \%$ & $0,00 \%$
\end{tabular}

Sumber : Pengolahan Data

Tabel 4. Coefficients

\begin{tabular}{cccccc}
\hline Term & Coef & SE Coef & T-Value & P-Value & VIF \\
\hline Constant & 280966 & 158103 & 1,78 & 0,136 & \\
X1 & $-41,6$ & 30,7 & $-1,35$ & 0,234 & 14,16 \\
X2 & $-12,47$ & 7,48 & $-1,67$ & 0,157 & 24,16 \\
X3 & 33,4 & 14,2 & 2,35 & 0,065 & 130,44 \\
X4 & $-20,7$ & 20,2 & $-1,03$ & 0,352 & 74,70 \\
\hline
\end{tabular}

Sumber : Pengolahan Data

Regression Equation

$\mathrm{Y}=280966-41,6 \mathrm{X} 1-12,47 \mathrm{X} 2+33,4 \mathrm{X} 3-20,7 \mathrm{X} 4$

Tabel 5. Fits and Diagnostics for Unusual Observation

\begin{tabular}{cccccc}
\hline Obs & Y & Fit & Residual & Std Residual & \\
\hline 6 & 104003 & 91546 & 12457 & 2,23 & $\mathrm{R}$ \\
8 & 82830 & 69031 & 13799 & 2,13 & $\mathrm{R}$ \\
\hline
\end{tabular}

Sumber : Pengolahan Data

R Large Residual

Durbin-Watson Statistic $=3,19619$ 


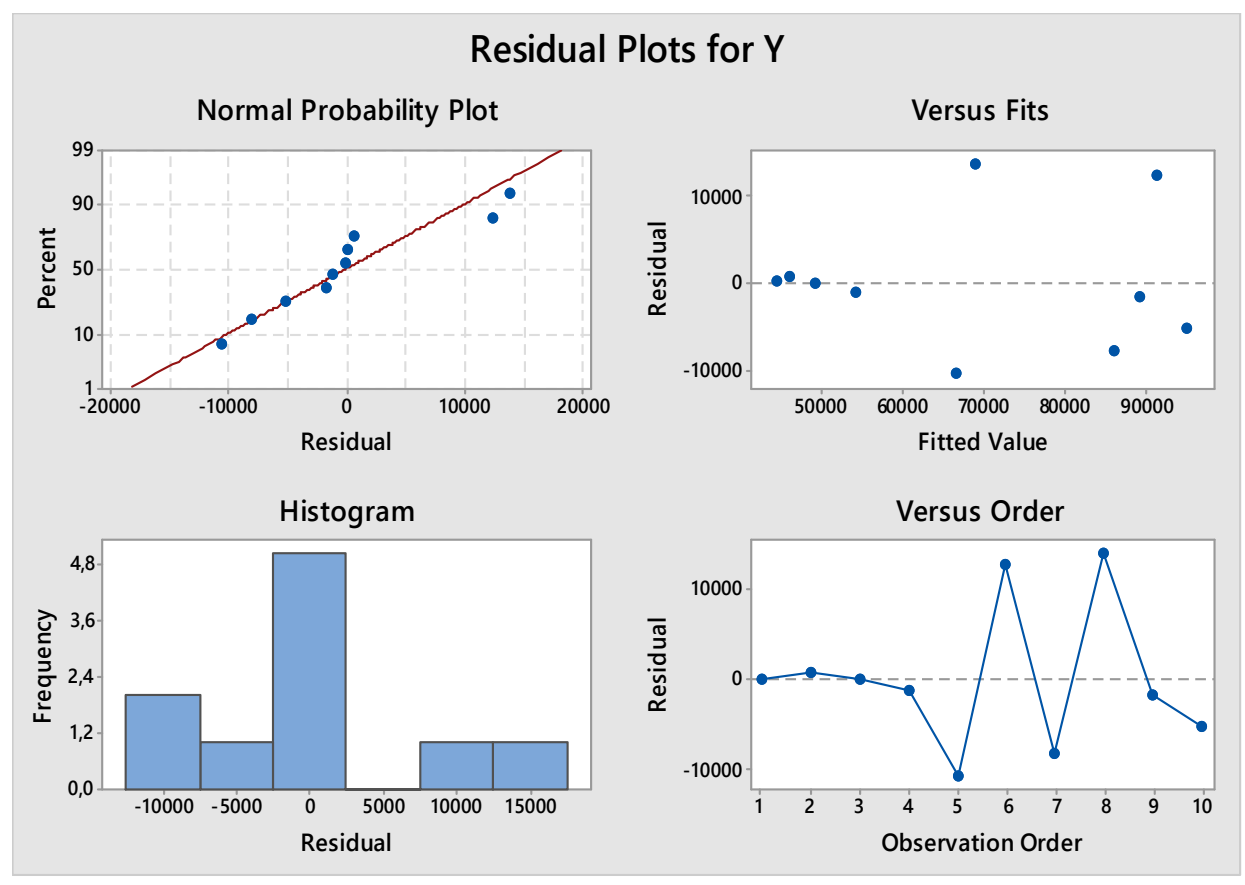

Berdasarkan model persamaan Regresi linear :

$\mathrm{Y}=280966-41,6 \mathrm{X} 1-12,47 \mathrm{X} 2+33,4 \mathrm{X} 3-20,7 \mathrm{X} 4$

Apabila variabel independen yaitu jumlah siswa SMK, jumlah anggaran, kebutuhan industri dan jumlah SMK bernilai konstan maka Nilai Y atau Jumlah Guru mata pelajaran Produktifdengan sendirinya akan berubah sebesar nilai konstanta yaitu 280966. Untuk jumlah siswa ( $\beta=-41,6$ ): Nilai ini menunjukkan bahwa ketika jumlah siswa SMK meningkat satu orang, Jumlah Guru mata pelajaran Produktif menurun atau berkurang sebanyak41,6guru. Salah satu variabel yaitu jumlah siswa SMK dalam ribuan, oleh karena itu, untuk setiap 1.000 dari jumlah siswa SMK, dihasilkan pengurangan atau penurunan41,6guru. Interpretasi ini benar hanya jika Jumlah Anggaran, kebutuhan industri, dan jumlah SMK tetap konstan. Untuk jumlah anggaran $(\beta=-12,47)$ : Nilai ini menunjukkan bahwa ketika jumlah anggaran meningkat satu rupiah, Jumlah Guru mata pelajaran Produktif menurun atau berkurang sebesar 12,47guru. Salah satu variabel yaitu jumlah anggaran diukur dalam miliar, oleh karena itu, untuk setiap 1.000.000.000 yang dikeluarkan dari jumlah anggaran, dihasilkan pengurangan atau penurunanjumlah guru mata pelajaran produktif SMK 12,47guru. Interpretasi ini benar hanya jika jumlah siswa SMK, kebutuhan industri, dan jumlah SMK tetap konstan. Untuk kebutuhan industri $(\beta=$ 33,4): Nilai ini menunjukkan bahwa ketika kebutuhan industri naik satu unit, Jumlah Guru mata pelajaran Produktif naik33,4guru. Salah satu variabel yaitu kebutuhan industri diukur dalam ribuan, oleh karena itu, untuk setiap 1.000 kebutuhan industri, dihasilkan penambahan atau kenaikan 33,4 guru. Penafsiran ini benar hanya jika jumlah siswa SMK, jumlah anggaran, dan jumlah SMK tetap konstan. Untuk jumlah SMK $(\beta=-20,7)$ : Nilai ini menunjukkan bahwa ketika jumlah SMK meningkat atau naik satu unit, Jumlah Guru mata pelajaran Produktif menurun atau berkurang sebanyak20,7guru.. Interpretasi ini benar hanya jika jumlah siswa SMK, jumlah anggaran, dan kebutuhan industry tetap konstan. 
Tabel5.2Uji Model dan Aktual Jumlah Kebutuhan Guru Mata Pelajaran Produktif SMK

\begin{tabular}{cccc}
\hline Tahun & MLR & Aktual & $\begin{array}{c}\text { Persentase } \\
\text { Error } \mathbf{( \% )}\end{array}$ \\
\hline 2010 & 44.750 & 44.423 & 0,7 \\
2011 & 46.498 & 46.761 & 0,5 \\
2012 & 49.743 & 49.222 & 1 \\
2013 & 54.765 & 53.057 & 3,5 \\
2014 & 67.090 & 55.920 & 20 \\
2015 & 92.125 & 104.003 & 11 \\
2016 & 86.898 & 78.208 & 11 \\
2017 & 69.676 & 82.830 & 16 \\
2018 & 90.085 & 87.664 & 2,5 \\
2019 & 95.960 & 90.024 & 6,5 \\
Total & 692.112 & 697.590 & 0,8 \\
\hline
\end{tabular}

Sumber : Data diolah, 2019

\section{Kesimpulan}

Berdasarkan hasil pengolahan data dan analisis dalam penelitian ini maka disimpulkan bahwa bentuk model matematika dari persamaan regresi linear berganda pengadaan guru mata pelajaran produktif $\mathrm{SMK}$ adalah $: \mathrm{Y}=$ 280966-41,6 X1 - 12,47 X2 + 33,4 X3 $-20,7$ X4. Dimana dari keempat variabel bebas atau kendala, hanya variabel kebutuhan industri yang mempunyai nilai positif, sementara ketiga variabel yang lain yaitu jumlah siswa SMK, jumlah anggaran dan jumlah SMK bernilai negatif.

Adanya gejala multikolinearitas pada data yang menyebabkan nilai standar error menjadi besar, dan nilai Koefisien Beta (B) tidak dapat mengukur variabel terikat yaitu kebutuhan guru mata pelajaran produktif SMK secara presisi.

\section{Daftar Pustaka}

Akpan, N. P., \& Iwok, I. A. (2016). Application of Linear Programming for Optimal Use of Raw Materials in Bakery. International Journal of
Mathematics and Statistics Invention, 4(8), 51-57.

Badan Pusat Statistik. Berita Resmi

Statistik, 06 November 2017.

Bakar, R. (2018). The Influence of Profesional Teachers on Padang Vocational school students achievement, Kasetsart Journal of Social Science, 039(1), 67-72.

Darmi (2012). Kompetensi Guru Produktif Dalam Meningkatkan Sikap Kewirausahaan Siswa Pada SMK Negeri 3 Banda Aceh.Jurnal Pencerahan, 6(1), 10-16

Direktorat Pembinaan SMK, (2017).Pola Kebijakan Pengembangan Guru Produktif Berdasarkan Inpres Nomor 9 tahun 2016.

Direktorat Pembinaan SMK, (2017).Rencana Strategis Direktorat Pembinaan SMK 2015 - 2019.

Djatmiko, I.W. (2012), Pengembangan Keprofesionalan Guru Sekolah Menengah Kejuruan. Ringkasan Disertasi, Pendidikan Teknologi dan Kejuruan, Universitas Negeri Yogyakarta, Indonesia.

E Peter, E., \& Helen, E. (2018). Design 
and Implementation of Mathematical Model for Revenue Management in Hospitality Industry. Journal of Hotel and Business Management, 07(01), $1-5$. https://doi.org/10.4172/2169-0286.1 000175

Farizal, Rachman, A., \& Rasyid, H. Al. (2014). Model Peramalan Konsumsi Bahan Bakar Jenis Premium Di Indonesia Dengan Regresi Linier Berganda. Jurnal Ilmiah Teknik Industri, 13(2), 166-176.

Ganefri, \& Hidayat, H. (2015), Production Based Learning: An Instructional Design Model in the Context of Vocational Education and Training (VET), Procedia Social and Behavioral Science, 204, 206-211.

Groff, J.F. (2013), Dynamic Systems Modelling in Educational System Design \& Policy, New Approaches In Educational Research, 2(2), 72-81.

Li, J., Meerkov, S. M., Li, J., \& Meerkov, S. M. (2008). Mathematical Modeling of Production Systems.Production Systems Engineering, 1-59. https://doi.org/10.1007/978-0-387-7 5579-3 3

Permai, S. D., \& Tanty, H. (2018). Linear regression model using bayesian approach for energy performance of residential building. Procedia Computer Science, 135, 671-677. https://doi.org/10.1016/j.procs.2018. 08.219

Rasto. (2016). Pendidikan Kejuruan. Retrieved from http://rasto.staf.upi.edu.

Salim, S. (2014). Upaya Peningkatan Kompetensi Profesional Guru Sekolah Kejuruan.

Sutirman. (2017). Menggagas Model Peningkatan Profesionalitas Guru SMK Administrasi Perkantoran Melalui Pelatihan Berbasis
Kompetensi.Seminar Nasional Entrepreneurship dan ProfesionalitasGuru di Era MEA. Yogyakarta: Indonesia.

Sulistyono, S., \& Sulistiyowati, W. (2018). Peramalan Produksi dengan Metode Regresi Linier Berganda. PROZIMA (Productivity, Optimization and Manufacturing System Engineering), $1(2)$, 82. https://doi.org/10.21070/prozima.v1i2.1 350

Vafaeinezhad, M., Kia, R., \& Shahnazari-Shahrezaei, P. (2016). Robust optimization of a mathematical model to design a dynamic cell formation problem considering labor utilization.Journal of Industrial Engineering International, 12(1), 45-60. https://doi.org/10.1007/s40092-015-012 7-5

Yang, X.-S. (2008). Introduction to mathematical optimization. In Introduction to Mathematical Optimization. Retrieved from http://f3.tiera.ru/2/M_Mathematics/M Oc_Optimization and control/Yang X.-S. Introduction to mathematical optimization (Cambridge ISP, 2008)(ISBN 1904602827)(O)(161s)_MOc_.pdf 